\title{
Oil extraction in the Amazon basin and exposure to metals in indigenous populations
}

Cristina O'Callaghan-Gordo ${ }^{1,2,3}$, Juan A. Flores ${ }^{4}$, Pilar Lizárraga ${ }^{4}$, Tami Okamoto ${ }^{5}$, Diana M. Papoulias ${ }^{6}$, Federica Barclay ${ }^{7}$, Martí Orta-Martínez ${ }^{8,9,10}$, Manolis Kogevinas ${ }^{1,2,3,11}$, John Astete ${ }^{4}$

${ }^{1}$ ISGlobal, Barcelona, Spain; ${ }^{2}$ Universitat Pompeu Fabra (UPF), Barcelona, Catalonia, Spain; ${ }^{3}$ CIBER Epidemiología y Salud Pública (CIBERESP), Madrid, Spain; ${ }^{4}$ National Institute of Health - Centro Nacional de Salud ocupacional y Protección del Ambiente para la Salud (CENSOPAS), Lima, Peru; ${ }^{5}$ Pontificia Unviersidad Católica del Perú, Lima, Peru; ${ }^{6}$ E-Tech International, Santa Fe, NM, USA; ${ }^{7}$ Centro de políticas Públicas y Derechos Humanos - Perú Equidad, Lima, Peru; ${ }^{8}$ International Institute of Social Studies, Erasmus University Rotterdam, The Hague, The Netherlands; ${ }^{9}$ Institut de Ciència i Tecnologia Ambiental, Universitat Autònoma de Barcelona, 08193 Bellaterra, Barcelona, Catalonia, Spain; ${ }^{10}$ Instituto de Geografía, Universidad San Francisco de Quito, Quito, Ecuador; ${ }^{11}$ Municipal Institute of Medical Research (IMIM-Hospital del Mar), Barcelona, Spain.

Corresponding author:

Cristina O'Callaghan-Gordo, PhD

email: cristina.ocallaghan@isglobal.org;

postal address: ISGlobal, Barcelona Institute for Global Health - Campus Mar, 88 Doctor Aiguader Rd., 08003 Barcelona, Spain;

phone number: +34 932147321 


\section{Abstract}

Most oil extraction areas in the Peruvian Amazon are within indigenous territories. Poor environmental practices have exposed the indigenous population to metals. We conducted a survey in two indigenous Kukama communities to assess body burdens of metals after the occurrence of two major oil spills in 2014. Urine levels above those recommended by the Peruvian Ministry of Health were observed in $50 \%$ and $17 \%$ of the study population for mercury and cadmium, respectively.

\section{Keywords}

Indigenous health; oil extraction; metals; mercury; cadmium; Peru 


\section{Funding sources}

This work was supported by the Ministry of Health, Peru (MINSA) 


\section{Background}

The Western Amazon contains large reserves of oil and gas (Finer et al., 2008). In the northern Peruvian Amazon, oil concessions known as Blocks $1 \mathrm{AB}$ and 8 were drawn at the late 1960 over the whole of the Corrientes, Pastaza and Tigre river basins (Loreto, Peru), tributary rivers of the Marañon river (figure 1). More than 45,000 Achuar, Kichwa and Urarina indigenous people live in these river basins.

Crude oil, produced waters and drilling muds can contain a number of potentially toxic agents, including heavy metals, such as lead, cadmium, arsenic and mercury amongst others (E\&P Forum/UNEP, 1997; Fakhru'l-Razi et al., 2009; Lienemann et al., 2007; Neff, 2002; Wilhelm, 1999). Poor environmental practices by the oil industry, such as the dumping of around 1 million barrels/day of produced water on soils and rivers in the study area, and recurrent oil spills have contaminated the Corrientes, Pastaza, and Tigre river basins, all tributary rivers of the Marañon river (Figure 1) and exposed the indigenous population to metals among other contaminants (Orta-Martínez et al., 2018; Orta Martínez et al., 2007). Since the 80's different Peruvian state agencies reported high levels of hydrocarbons and heavy metals related to oil extraction activities in environmental samples, and high levels of cadmium and lead in blood among the local population of this area (Orta Martínez et al., 2007). Exposure to metals is associated with several negative health outcomes, including neurological, respiratory, renal and cardiovascular effects, and increased risk of cancer (Järup, 2003; Vrijheid et al., 2016).

The $30^{\text {th }}$ of June 2014, an oil spill of the Northern Peruvian pipeline (ONP, by its Spanish acronym) released 2,358 barrels of crude oil to the environment, coating over 87,000 square meters of the territory of the indigenous community of Cuninico (Expediente Resolución Directoral No. 844-2015-OEFA/DFSAI Expediente No. 13062014-OEFA/DFSAI/PAS. 2015; UTM WGS84 N9474535, E467992). A few months later, the $16^{\text {th }}$ of November 2014 , an oil spill in the same region released approximately 7,800 barrels of crude affecting the territory of the indigenous community of San Pedro 
(Goldenberg, 2014). Approximately one year after these major spills, we surveyed these two Kukama communities to assess blood and urine levels of metals often found in crude oil.

\section{Methods}

In January 2016, CENSOPAS-INS, the centre for occupational and environmental health of the Peruvian National Institute of Health, conducted an assessment of metal concentrations in the inhabitants of Cuninico and San Pedro. Participation was offered to all inhabitants that had been living in these communities during at least the previous six months. The study protocol was reviewed and accepted by the Ethics Committee (Comité Institucional de Ética en Investigación) of the National Institute of Health, Peru. All participating subjects provided written informed consent.

Demographic data and information on involvement in oil clean-up activities were collected through structured questionnaires. Venous blood and urine were collected, and preserved following standardized CENSOPAS-INS procedures (Carreón Valencia et al., 1995; Centers for Disease Control and Prevention, 2016). Concentration of metals were determined using protocols validated by CENSOPAS-INS. Specifically, atomic absorption spectrophotometry (AAS) in graphite chamber was used for lead in blood (Instituto Nacional de Seguridad e Higiene en el Trabajo. Ministerio de de trabajo y asuntos sociales España, n.d.) and for cadmium in urine (adapted version of (NIOSH, 1994)). Flow injection -hydride generation AAS was used for arsenic in urine (adapted version of (Intersociety Committee \& Morris Katz, 1989)) and cold vapour AAS was used for mercury in urine (Instituto Nacional de Seguridad e Higiene en el Trabajo. Ministerio de de trabajo y asuntos sociales España, n.d.). Creatinine in urine was measured by mass spectrophotometry using kinetic Jaffe method (Wiener Lab. Ref 1260360). 
Method limits of detection (LOD) applied were $2 \mu \mathrm{g} / \mathrm{dL}$ for lead, $2.5 \mu \mathrm{g} / \mathrm{L}$ for arsenic and mercury, and $0.5 \mu \mathrm{g} / \mathrm{L}$ for cadmium. We replaced metal values below the LOD by LOD/2. To account for urinary dilution, we corrected levels of arsenic, cadmium, and mercury with creatinine concentrations, when creatinine values where within acceptable ranges for human biomonitoring $(>0.3-<3.0 \mathrm{~g} / \mathrm{L})$ (American Conference Of Governmental Industrial Hygienists (ACGIH), 2017). Samples with creatinine values outside this range were not included in the analysis. For all metals under study, we used as reference values those established by the Peruvian Ministry of Health (MINSA): $<10 \mu \mathrm{g}$ lead/dL blood, $20 \mu \mathrm{g}$ arsenic/g creatinine, $2 \mu \mathrm{g}$ cadmium/g creatinine and $5 \mu \mathrm{g}$ mercury/g creatinine.

We conducted descriptive analyses of the study population characteristics and levels of metals. We examined the distribution levels of metals among the study population. As levels of metals among the study participants did not follow a normal distribution, we compared median levels of metals according to demographic characteristics using nonparametric tests (i.e. Wilcoxon rank-sum test for variables with two categories and Kruskal-Wallis test for variables with more than two categories). Correlation between levels of metals was tested using Spearman's rank correlation coefficient. Levels of metals were log transformed to approach normal distribution. Association between selfreported involvement in clean-up activities and levels of metals (log transformed) was studied among the overall population using linear regression models adjusted for age and sex.

\section{Results}

Nine percent of the population (132/1400) participated in the survey. Blood and urine were collected from $98 \%$ and $95 \%$ of the study population, respectively. Urine creatinine values for 13 samples were outside the acceptable range and were not included in the analysis. 
Median (interquartile range) blood lead levels were $2.4 \mu \mathrm{g} / \mathrm{dL}$ (1.6). Median levels of other metals in urine were: arsenic 3.1 (3.0) $\mu \mathrm{g} / \mathrm{g}$, cadmium 1.1 (1.0) $\mu \mathrm{g} / \mathrm{g}$, and mercury $5.1(5.3) \mu \mathrm{g} / \mathrm{g}$. Concentrations of the different metals were not correlated (Spearman's correlation coefficients: lead-arsenic $=0.23$; lead-cadmium $=0.10$; lead-mercury $=0.04$; As-cadmium $=-0.03 ;$ As-mercury $=0.02$; cadmium-mercury $=0.30$ ). Men had higher levels of lead and arsenic than women. Levels of arsenic and mercury were higher in children $\leq 10$ years compared with the older population. Participants from the community of San Pedro had higher levels of cadmium and mercury than participants from Cuninico. Participants involved in clean-up activities had higher blood lead than those not involved in clean-up (Table 1).

Five per cent of children $\leq 10$ years exceeded blood lead levels recommended by the MINSA, and 19\% exceeded blood lead levels of $5 \mu \mathrm{g} / \mathrm{dL}$, the threshold used by the American Centers for Disease Control and Prevention (CDC) to identify children with the highest levels of exposure in a population (National Center for Environmental Health. Division of Emergency and Environmental Health Services, 2012). No participant exceeded arsenic benchmarks recommended by the MINSA. $17 \%$ and $50 \%$ of the study population exceeded levels recommended by the MINSA for cadmium and mercury, respectively. These percentages were higher among children $\leq 10$ years: $18 \%$ and $64 \%$ of them had cadmium and mercury levels higher than those recommended, respectively.

There was no association between an individual's body burden of metals and their participation in clean-up activities (Table 2).

\section{Discussion}

We report high levels of metals, particularly mercury, for the population of two indigenous communities of the northern Peruvian Amazon, located downstream of two 
major oil extraction blocks (block $1 \mathrm{AB} / 192$ and 8 ), and in the vicinity of a major oil pipeline (figure 1), 13 and 16 months after two major oil spills that affected their territories. Median levels of urine mercury in the overall population were above reference values established by the MINSA. Overall, $50 \%$ of the general population and $64 \%$ of children $\leq 10$ years had levels of mercury higher than those recommended. These results are concerning as exposure to mercury is associated with neurological and psychological symptoms (, among others health effects including renal, respiratory and cardiovascular effects (Rice et al., 2014). Children (and pregnant women) are especially vulnerable to the effect of mercury, as damages in central nervous system are more critical during early development (Debes et al., 2016; Grandjean and White, 2002).

Crude oil and produced waters can contain mercury (Fakhru'l-Razi et al., 2009; Lienemann et al., 2007; Wilhelm, 1999), and elevated levels of mercury have been reported in the environment and aquatic organisms (i.e. methyl mercury) around oil extraction sites and in areas affected by oil spills (reviewed in (Webb et al., 2016)). A recent study conducted among indigenous peoples living close to oil extraction sites, in communities located upstream from Cuninico and San Pedro (Pastaza and Corrientes river basins), also reported high levels of inorganic mercury in urine (Webb et al., 2016). Nevertheless, some authors have suggested that demethylation of organic mercury (i.e. methyl mercury) can occur in the human body and therefore, part of the mercury detected in urine (i.e inorganic mercury) could come from organic sources such as fish ingestion (Abdelouahab et al., 2008; Passos et al., 2007). Mercury contamination of fish is widely spread in the region and it is well known health risk affecting many of the indigenous peoples living along the Amazonian rivers and tributaries who rely on subsistence fishing (Faial et al., 2015; Olivero-Verbel et al., 2016; Weinhouse et al., 2017). 
We could not assess if demethylation was an important source of inorganic mercury levels in urine. Webb et al. (Webb et al., 2016), concluded that demethylation was not an important source of inorganic mercury in their study population, and suggested that the main source of mercury in for population of area could be related to oil extraction activities (Webb et al., 2016). Nevertheless, several studies have identified deforestation, soil erosion and gold mining as the major sources of mercury emission into the Amazonian ecosystems. Given the presence of such activities (i.e. illegal gold mining and deforestation) in the Marañon River basin (Instituto del Bien Común, 2016), we cannot exclude these sources as other potential sources of mercury contamination in the communities of Cuninico and San Pedro.

The median levels of cadmium in urine in the study population were below the reference values established by MINSA. However, $17 \%$ of the study population and $18 \%$ of children $\leq 10$ years had cadmium levels above these benchmarks. Cadmium exposure causes kidney damage, including chronic renal failure. Long term exposure to high levels of cadmium can cause skeletal damage (itai-itai disease) (Åkesson et al., 2014; Järup, 2003). Also, cadmium is carcinogenic, causing lung, prostate and kidney cancer (IARC, 2012).

Cadmium can be naturally present in oil and produced waters (Fakhru'l-Razi et al., 2009; Lienemann et al., 2007; Neff, 2002). A recently published meta-analysis of water quality data collected by various Peruvian state institutions concluded that produced water was a source of 0.34 Metric tons of cadmium/year in the surface waters of the Corrientes, Pastaza, Tigre, and Marañon rivers (Yusta-García et al., 2017). Also, measurable levels of cadmium were found in sediments near the oil spill two years after its occurrence (SINADA ODLO-0016-2016 / 2016-E01-053799), available from the authors). Cadmium released onto soils or into surface waters can be taken up by plants (i.e. leafy vegetables, root crops, cereals and grains) and thus enter the food chain (Agency for Toxic Substances and Disease Registry, 2008). Human exposure to 
cadmium also occurs through consumption of contaminated water or inhalation. Very high levels of cadmium in urine have been previously reported among indigenous peoples living in other areas of the $1 \mathrm{AB} / 192$ and 8 oil blocks the Corrientes river basin (DIGESA, 2006).

Another important source of cadmium exposure is cigarette smoking. However, information about cigarette use was not available for our study population but there is a low percentage of smokers in the indigenous communities from these four river basins ( $<10 \%$, CENSOPAS-INS unpublished data), and those that do smoke, do so only occasionally ( $41 \%$ of smokers smoke less than one cigarette per week. CENSOPASINS unpublished data).

The median levels of lead in blood were $2.4 \mu \mathrm{g} / \mathrm{dL}$ (1.6). Although no blood lead level is considered safe, a benchmark of $5 \mu \mathrm{g} / \mathrm{dL}$ is used by the CDC to identify children at highest risk in a population based on the distribution of blood lead levels in the American population (National Center for Environmental Health. Division of Emergency and Environmental Health Services, 2012). Nineteen percent of children under 10 years in the study population had blood concentrations above this value. The main health effects of lead exposure are neurological and behavioural effects, including reduced intellectual capacity. Also lead is classified as probably carcinogenic to humans by the IARC (IARC Working Group on the Evaluation of Carcinogenic Risks to Humans, 2006).

Lead can be present in crude oil and produced waters (Fakhru'l-Razi et al., 2009; Lienemann et al., 2007; Neff, 2002). The meta-analysis by Yusta-Garcia et al (YustaGarcía et al., 2017) concluded that produced waters historically were an important source of lead contamination in the Corrientes, Pastaza, Tigre, and Marañon river basins (5.14 Metric tons/year). The presence of lead in the produced waters of the same oil block suggests that lead could be present in the spilled crude oil and could 
therefore have been a source of exposure for inhabitants of Cuninico and San Pedro. Moreover, high levels of lead were found in sediments near the oil spill two years after its occurrence (SINADA ODLO-0016-2016 and 2016-E01-053799; available from the authors). High blood lead levels have been previously reported among indigenous peoples from the Corrientes river basin (Anticona et al., 2012; DIGESA, 2006).

Our findings show that levels of metals do not correlate between them. We would expect them to correlate if they were all found in the spilled crude and increased in the environment as a result. However, each metal has different uptake-times and half-lives in the environmental matrices to which the people were exposed (water, vegetables, game and fish amongst others) and different half-lives in the human body. The current study was conducted several months after the oil spills, which might have affected detection of metals with short half-life (such as arsenic). This is the main limitation of the current study. The long time between oils spill and the study, also makes associating participation in clean-up activities and body levels of metals difficult. However, we can not exclude other sources the existence of other sources of these heavy metals, especially for mercury.

The study has several strengths. We report for the first time levels of four different metals measured simultaneously among indigenous communities of the Amazon living in the vicinity of an oil pipeline where oil spills are recurrent. We used standardized and validated protocols of CENSOPAS-INS to assess exposure and we sampled individuals from all ages, which allowed us to better describe exposure in the population overall.

\section{Conclusion}

In conclusion, individuals in these two communities located close to the North Peruvian pipeline have levels of mercury, cadmium and lead that can be detrimental to health. 
Recurrent oil spills, may be a source of exposure to these metals, although we cannot exclude the existence of other sources of exposure, especially for mercury. Assessing the specific source of exposure to these metals was not within the scope of this survey and future studies designed to elucidate the sources of contamination are warranted to help prevent continued exposure to inhabitants in this oil production zone. We recommend that human bio-monitoring be started soon after an oil spill in order to collect data that better reflects occupational and incidental exposure to oil-related contaminants. 


\section{References}

Abdelouahab, N., Vanier, C., Baldwin, M., Garceau, S., Lucotte, M., Mergler, D., 2008. Ecosystem matters: fish consumption, mercury intake and exposure among fluvial lake fish-eaters. Sci. Total Environ. 407, 154-64.

https://doi.org/10.1016/j.scitotenv.2008.09.004

Agency for Toxic Substances and Disease Registry, 2008. Agency for Toxic Substances and Disease Registry [WWW Document]. URL https://www.atsdr.cdc.gov/csem/csem.asp?csem=6\&po=6 (accessed 7.3.17).

Åkesson, A., Barregard, L., Bergdahl, I.A., Nordberg, G.F., Nordberg, M., Skerfving, S., 2014. Non-renal effects and the risk assessment of environmental cadmium exposure. Environ. Health Perspect. 122, 431-8.

https://doi.org/10.1289/ehp.1307110

American Conference Of Governmental Industrial Hygienists (ACGIH), 2017. TLV/BEI Guidelines [WWW Document].

Anticona, C., Bergdahl, I.A., Sebastian, M.S., 2012. Lead exposure among children from native communities of the Peruvian Amazon basin 31, 296-302.

Carreón Valencia, T., López Carrillo, L., Romieu, I., 1995. Manual de Prodecimiento en la Toma de Muestras Biológicas y Ambientales para Determinar Niveles de Plomo. Metepec, México.

Centers for Disease Control and Prevention, 2016. NIOSH Manual of Analytical Methods 4th Edition - Method Number 8310 [WWW Document]. URL https://www.cdc.gov/niosh/docs/2003-154/pdfs/8310.pdf (accessed 11.22.17).

Debes, F., Weihe, P., Grandjean, P., 2016. Cognitive deficits at age 22 years associated with prenatal exposure to methylmercury. Cortex 74, 358-369. https://doi.org/10.1016/j.cortex.2015.05.017

DIGESA, 2006. Evaluación de resultados del monitoreo del río Corrientes y toma de 
muestras biológicas, en la intervención realizada del 29 de junio al 15 de julio del 2005 Informe No-2006/DEPA-APRHI/DIGESA . 32.

E\&P Forum/UNEP, 1997. Environmental management in oil and gas exploration and production. An overview of issues and management approaches. London.

Faial, K., Deus, R., Deus, S., Neves, R., Jesus, I., Santos, E., Alves, C.N., Brasil, D., 2015. Mercury levels assessment in hair of riverside inhabitants of the Tapajós River, Pará State, Amazon, Brazil: Fish consumption as a possible route of exposure. J. Trace Elem. Med. Biol. 30, 66-76. https://doi.org/10.1016/j.jtemb.2014.10.009

Fakhru'l-Razi, A., Pendashteh, A., Abdullah, L.C., Biak, D.R.A., Madaeni, S.S., Abidin, Z.Z., 2009. Review of technologies for oil and gas produced water treatment. J. Hazard. Mater. 170, 530-51. https://doi.org/10.1016/j.jhazmat.2009.05.044

Finer, M., Jenkins, C.N., Pimm, S.L., Keane, B., Ross, C., 2008. Oil and gas projects in the Western Amazon: Threats to wilderness, biodiversity, and indigenous peoples. PLoS One 3. https://doi.org/10.1371/journal.pone.0002932

Goldenberg, S., 2014. The Amazon oil spills overlooked by environmental leaders in Lima. Guard.

Grandjean, P., White, R., 2002. Neurodevelopmental disorders, in: Tamburlini, G., von Ehrenstein, O.S., Bertollini, R. (Eds.), Children's Health and Environment: A Review of Evidence. WHO Regional Office for Europe, Copenhaguen, p. 66-78. IARC, 2012. A Review of Human Carcinogens: Arsenic, Metals, Fibres, and Dusts. IARC Monogr. Eval. Carcinog. Risks Hum. 100C, 11-465.

IARC Working Group on the Evaluation of Carcinogenic Risks to Humans, 2006. Inorganic and organic lead compounds. IARC Monogr. Eval. Carcinog. risks to humans $87,1-471$.

Instituto del Bien Común, 2016. Presiones y amenazas sobre áreas naturales 
protegidas y territorios indígenas. Deforestación 200-2013. Loreto 2016. Lima (Peru).

Instituto Nacional de Seguridad e Higiene en el Trabajo. Ministerio de de trabajo y asuntos sociales España, n.d. Determinación de plomo en sangre - Método de cámara de grafito Espectrofotometría de absorción atómica. MTA/MB-011/R92 [WWW Document].

Instituto Nacional de Seguridad e Higiene en el Trabajo. Ministerio de de trabajo y asuntos sociales España, n.d. Determinación de mercurio en orina - Método del vapor frío con cloruro de estaño / Espectrofotometría de absorción atómica. MTA/MB-019/A94 [WWW Document].

Intersociety Committee \& Morris Katz, 1989. Methods of air sampling and analysis / APHA Intersociety Committee, 3rd ed. Lewis Publishers, New York.

Järup, L., 2003. Hazards of heavy metal contamination. Br. Med. Bull. 68, 167-182. https://doi.org/10.1093/bmb/ldg032

Lienemann, C.P., Dreyfus, S., Pecheyran, C., Donard, O.F.X., 2007. Trace Metal Analysis in Petroleum Products: Sample Introduction Evaluation in ICP-OES and Comparison with an ICP-MS Approach. Oil Gas Sci. Technol. - Rev. I'IFP 62, 6977. https://doi.org/10.2516/ogst:2007006

National Center for Environmental Health. Division of Emergency and Environmental Health Services, 2012. Lead [WWW Document]. URL https://www.cdc.gov/nceh/lead/acclpp/blood_lead_levels.htm (accessed 7.13.17). Neff, J.M., 2002. Bioaccumulation in Marine Organisms. Effect of Contaminants from Oil Well Produced Water. Elsevier Ltd, Duxbury, MA, USA. NIOSH, 1994. Method 8003 - Manual of Analytical Method. Fourth Edition [WWW Document].

Olivero-Verbel, J., Carranza-Lopez, L., Caballero-Gallardo, K., Ripoll-Arboleda, A., 
Muñoz-Sosa, D., 2016. Human exposure and risk assessment associated with mercury pollution in the Caqueta River, Colombian Amazon. Environ. Sci. Pollut. Res. 20761-20771. https://doi.org/10.1007/s11356-016-7255-3

Orta-Martínez, M., Rosell-Melé, A., Cartró-Sabaté, M., O’Callaghan-Gordo, C., Moraleda-Cibrián, N., Mayor, P., 2018. First evidences of Amazonian wildlife feeding on petroleum-contaminated soils: A new exposure route to petrogenic compounds? Environ. Res. 160, 514-517. https://doi.org/10.1016/j.envres.2017.10.009

Orta Martínez, M., Napolitano, D. a, MacLennan, G.J., O'Callaghan, C., Ciborowski, S., Fabregas, X., 2007. Impacts of petroleum activities for the Achuar people of the Peruvian Amazon: summary of existing evidence and research gaps. Environ. Res. Lett. 2, 45006. https://doi.org/10.1088/1748-9326/2/4/045006

Passos, C.J.S., Mergler, D., Lemire, M., Fillion, M., Guimarães, J.R.D., 2007. Fish consumption and bioindicators of inorganic mercury exposure. Sci. Total Environ. 373, 68-76. https://doi.org/10.1016/j.scitotenv.2006.11.015

Rice, K.M., Walker, E.M., Wu, M., Gillette, C., Blough, E.R., 2014. Environmental Mercury and Its Toxic Effects. J. Prev. Med. Public Heal. 47, 74-83. https://doi.org/10.3961/jpmph.2014.47.2.74

Vrijheid, M., Casas, M., Gascon, M., Valvi, D., Nieuwenhuijsen, M., 2016.

Environmental pollutants and child health-A review of recent concerns. Int. J. Hyg. Environ. Health 219, 331-342. https://doi.org/10.1016/j.ijheh.2016.05.001

Webb, J., Coomes, O.T., Ross, N., Mergler, D., 2016. Mercury concentrations in urine of amerindian populations near oil fields in the peruvian and ecuadorian amazon. Environ. Res. 151, 344-350. https://doi.org/10.1016/j.envres.2016.07.040

Weinhouse, C., Ortiz, E.J., Berky, A.J., Bullins, P., Hare-Grogg, J., Rogers, L., Morales, A.-M., Hsu-Kim, H., Pan, W.K., 2017. Hair Mercury Level is Associated with 
Anemia and Micronutrient Status in Children Living Near Artisanal and SmallScale Gold Mining in the Peruvian Amazon. Am. J. Trop. Med. Hyg. 97, 18861897. https://doi.org/10.4269/ajtmh.17-0269

Wilhelm, S.M., 1999. Generation and Disposal of Pe t ro I e u m Processing Waste That Contains Me rc u ry. Environ. Prog. 18.

Yusta-García, R., Orta-Martínez, M., Mayor, P., González-Crespo, C., Rosell-Melé, A., 2017. Water contamination from oil extraction in Northern Peruvian Amazonian rivers. Environ. Sci. Technol. https://doi.org/10.1016/j.envpol.2017.02.063 
Table 1. Description of study population and median concentration of lead $(\mathrm{Pb})$ in blood and arsenic (As), cadmium (Cd) and mercury ( $\mathrm{Hg})$ in urine by study population characteristics

\begin{tabular}{|c|c|c|c|c|c|c|c|c|c|}
\hline \multirow[t]{2}{*}{ Variables } & \multirow[t]{2}{*}{$n(\%), n=132$} & \multicolumn{2}{|c|}{$\mathrm{Pb}(\mu \mathrm{g} / \mathrm{dL}), \mathrm{n}=129^{*}$} & \multicolumn{2}{|c|}{ As ( $\mu \mathrm{g} / \mathrm{g}$ creatinine), $\mathrm{n}=113^{\text {** }}$} & \multicolumn{2}{|c|}{ Cd ( $\mu$ g/g creatinine), $n=113^{* *}$} & \multicolumn{2}{|c|}{$\mathrm{Hg}(\mu \mathrm{g} / \mathrm{g}$ creatinine $), \mathrm{n}=113^{* *}$} \\
\hline & & Median (IQR) & $p$-value ${ }^{\S}$ & median (IQR) & $p$-value ${ }^{\S}$ & median (IQR) & $p$-value ${ }^{\S}$ & median (IQR) & $p$-value ${ }^{\S}$ \\
\hline \multicolumn{10}{|l|}{ Sex } \\
\hline Men & $69(52)$ & $3.17(2.37)$ & & $3.61(2.40)$ & & $1.00(0.94)$ & & $4.84(5.41)$ & \\
\hline \multicolumn{10}{|l|}{ Age (years) } \\
\hline$\leq 10$ & $37(28)$ & $2.48(2.36)$ & & $3.61(3.77)$ & & $0.92(1.04)$ & & $6.85(6.60)$ & \\
\hline $11-20$ & $24(18)$ & $2.00(2.27)$ & & $3.25(2.51)$ & & $0.77(0.61)$ & & $3.76(4.01)$ & \\
\hline $31-40$ & $18(14)$ & $2.12(2.46)$ & & $2.09(2.92)$ & & $1.18(0.7)$ & & $6.21(4.00)$ & \\
\hline $41-50$ & $15(11)$ & $2.00(2.96)$ & & $2.07(1.05)$ & & $1.13(0.85)$ & & $4.45 \quad(3.16)$ & \\
\hline$>50$ & $23(17)$ & $2.56(1.61)$ & 0.257 & $2.55(2.80)$ & 0.040 & $1.66(1.30)$ & 0.011 & $5.10(6.02)$ & 0.060 \\
\hline \multicolumn{10}{|l|}{$\begin{array}{l}\text { Children } \\
\text { Yes }(\leq 10\end{array}$} \\
\hline years) & $37(28)$ & $2.48(2.36)$ & & $3.61(3.77)$ & & $0.92(1.04)$ & & $6.85(6.60)$ & \\
\hline No (> 10 years) & $95(72)$ & $2.21(2.54)$ & 0.072 & $2.60(2.78)$ & 0.009 & $1.15(0.86)$ & 0.158 & $4.45(4.19)$ & 0.047 \\
\hline \multicolumn{10}{|c|}{ Clean-up activities } \\
\hline No & $101(80)$ & $2.16(2.35)$ & & $3.19(2.83)$ & & $1.17(1.05)$ & & $5.40(5.65)$ & \\
\hline Yes & $26(20)$ & $3.30(2.02)$ & 0.004 & $2.29(2.97)$ & 0.400 & $0.99(0.60)$ & 0.325 & $3.96(3.41)$ & 0.102 \\
\hline
\end{tabular}


"Measurement of lead levels in blood was not available for 3 participants; "* Measurement of As, Cd and Hg in urine was not available for 19 participants; ${ }^{\S}$ Wilcoxon rank-sum test for variables with two categories and Kruskal wallis test for variables with more than two categories. IQR: inter quartile range 
Table 2. Association between blood or urine metal concentrations and participation in clean-up activities.

\begin{tabular}{llll}
\hline Exposure (log transformed) & Clean-up activities & N (\%) & Regression coefficient $(95 \% \mathbf{C l})^{*}$ \\
\hline Lead $(\mu \mathrm{g} / \mathrm{dL})$ & No & $101(80)$ & \\
& Yes & $26(20)$ & $0.08(-0.2,0.37)$ \\
Arsenic $(\mu \mathrm{g} / \mathrm{g}$ creatinine) & No & $87(78)$ & \\
& Yes & $24(22)$ & $-0.31(-0.61,-0.01)$ \\
cadmium $(\mu \mathrm{g} / \mathrm{g}$ creatinine $)$ & No & $87(78)$ & \\
& Yes & $24(22)$ & $-0.28(-0.59,0.03)$ \\
& No & $87(78)$ & \\
Mercury $(\mu \mathrm{g} / \mathrm{g}$ creatinine $)$ & Yes & $24(22)$ & $-0.34(-0.7,0.02)$ \\
& & & \\
\hline
\end{tabular}

*Adjusted for age and sex 
Figure 1. Map of the study area 